\title{
Relationship of methane and electricity production in two-chamber microbial fuel cell using sewage sludge as substrate
}

\author{
Benyi Xiao, Yunping Han, Xin Liu, Junxin Liu* \\ Research Center for Eco-Environmental Sciences, Chinese Academy of Sciences, Beijing 100085, China
}

\section{A R T I C L E I N F O}

\section{Article history:}

Received 21 May 2014

Received in revised form

1 August 2014

Accepted 10 August 2014

Available online 30 August 2014

Keywords:

Electricity production

Methane production

Relationship

Sewage sludge

Two-chamber microbial fuel cell

\begin{abstract}
A B S T R A C T
The relationship of methane and electricity production from sewage sludge in a twochamber microbial fuel cell (MFC) was studied. The results showed that methane production in the anode chamber could enhance the electricity production from sewage sludge, and the output voltage of the MFC with methane production $(0.505-0.600 \mathrm{~V})$ was higher than that of the MFC without it $(0.506-0.576 \mathrm{~V})$ in the stable electricity-producing stage. The polarization curves analysis of the two MFCs suggested that methane production could improve the performance characteristics of the MFC. Simultaneous methane and electricity production from sludge in the two-chamber MFC could maintain the mixed sludge in a suitable $\mathrm{pH}$ range in the anode chamber for electricity production. Meanwhile, simultaneous methane and electricity production could enhance the hydrolysis of sludge, which increased the reduction of sludge concentration (about $8.31 \%$ VSS) and offered more substrates to alleviate the competition between methane and electricity production. Additionally, the addition of 2-Bromoethanesulfonate (BES) could substantially affect the dominant archaea but had little effect on the dominant bacteria in the anode chamber. Copyright @ $\odot$ 2014, Hydrogen Energy Publications, LLC. Published by Elsevier Ltd. All rights
\end{abstract}

reserved.

\section{Introduction}

The microbial fuel cell (MFC) is a bio-electrochemical system that converts chemical energy to electrical energy in dissolved biomass by the catalytic reaction of microorganisms [11,20]. MFCs can produce electricity from a variety of matters including organic wastewater and wastes [17], such as potatoprocessing wastewater [4], starch processing wastewater [13], and sewage sludge $[5,8,25,33]$. Sewage sludge, a by-product of wastewater biological treatment, is an important organic waste [23]. The electricity production from sewage sludge by MFCs has become a study hotspot and an important method of sludge resource utilization because it contains abundant organic matters $[17,25]$.

In the operation of MFCs, methanogenesis is a common phenomenon, particularly when inoculated with mixed anaerobic sludge, since the growth conditions for methanogens are similar to those of exoelectrogens [2,21,33]. Many researchers have reported methane production in the electricity-producing process of MFCs, and the presence of methanogens in MFC systems has been confirmed via microscopic and PCR-based approaches [2,9,21,29,33]. For example [9], observed methane accumulation in the anode chamber headspace of an MFC, and $113.5 \mathrm{ml}$ methane was produced in the electricity production of an MFC with

\footnotetext{
* Corresponding author. Tel./fax: +86 1062849133.

E-mail address: jxliu@rcees.ac.cn (J. Liu).
} 
alkaline-pretreated sludge as fuel in our previous study [29]. Because it would compete actively with exoelectrogens for their substrates in the anode chamber, methanogenesis was believed to cause a decrease in the performance of MFCs, and it was thought that methanogenesis suppression could improve the performance of MFCs [2,21,33]. Chae et al. [2] found methanogenesis caused a significant decrease in the performance of MFCs and methanogenesis suppression could increase the coulombic efficiency of an MFC from 35\% to $70 \%$ and [21] also found methanogenesis suppression could increase current production and improve the coulombic efficiency of a cellulose-fed MFC. 2-Bromoethanesulfonate (BES) is a structural analog of 2-mercaptoethanesulfonate (coenzyme $\mathrm{M}$, a coenzyme unique to methanogenic bacteria) and a potent inhibitor of methanogenesis in vivo and in vitro [34]; Ref.). BES had been used as an inhibitor of methanogenesis in biohydrogen production and electricity production $[2,16,28,33]$. For example [2], used 0.1-0.27 mM BES could effectively inhibited the bioactivity of methanogens and did not affect exoelectrogens in two-chambered MFC.

However, in most studies on the effect of methane production on electricity production in MFCs, the electricity-producing substrates were simple organic matters or easily degradable compounds (like acetate, sodium acetate, glucose and cellulose) $[2,9,21]$. Unlike these simple organic matters and easily degradable compounds, most organic matters in sewage sludge are microbial in nature, and are compartmentalized within the microbial cell membranes [26,27]. The cell envelopes of microorganisms must be hydrolyzed before most organic matters of sludge can be used by various microorganisms. Although [33] found methanogenesis inhibition with $0.5 \mathrm{mM}$ BES could improve the performance of an air-cathode MFC with sewage sludge as substrate, they did not use anaerobic sludge as inoculum, and the methane production was low in the MFC without methanogenesis suppression. Additionally, in our previous study, although we found that the methane production and electricity production did not have an obvious relationship in a two-chamber MFC with alkaline-pretreated sludge as substrate [29], no control test with methanogenesis suppression was used. The relationship between electricity and methane production in sludge-fed MFCs with anaerobic sludge as seed is not clear.

Therefore, the object of this study is to investigate the relationship of methane and electricity production in a twochamber MFC using sewage sludge as electricity-producing substrate and anaerobic sludge as inoculum.

\section{Materials and methods}

\section{Experimental sludge and inoculum sludge}

The sewage sludge was obtained from the secondary sedimentation tank of a municipal wastewater treatment plant in Beijing, China, which uses an activated sludge process and handles 400,000 t wastewater daily. The anaerobic sludge, which was used as the inoculum for the anode chamber, was obtained from the anaerobic sludge digester of the same wastewater treatment plant. The collected sludge samples were filtered using a 40 mesh sieve to remove the larger particles and then settled by gravity for about $1 \mathrm{~h}$, and the sediments were stored at $4{ }^{\circ} \mathrm{C}$ before use. Some characteristics of the sewage sludge, anaerobic sludge and sludge mixture in the anode chamber are summarized in Table 1.

\section{MFC and its operation}

The two-chamber MFCs were constructed as previously described with $5 \mathrm{~cm}^{2}$ proton exchange membranes (Nafion117) [29]. The anodes and cathodes were made of carbon felt without wet-proofing (Yanye Co., China) and their sizes and distances were $4 \mathrm{~cm} \times 6 \mathrm{~cm} \times 0.5 \mathrm{~cm}$ and $14 \mathrm{~cm}$, respectively. Copper wire was used for connection to the external circuit, with $1000 \Omega$ fixed external resistance.

In the anode chamber of each MFC, $350 \mathrm{ml}$ sewage sludge and $50 \mathrm{ml}$ anaerobic sludge (as inoculum) were added, and in the cathode chambers, $315 \mathrm{ml}$ sewage sludge was added. As control, $2.1 \mathrm{~g}$ of the methanogen inhibitor (BES) was added into the anode chamber of one of the MFCs and the concentration of BES was about $25 \mathrm{mM}$. $5 \mathrm{ml}$ trace elements solution [12] was also added into each chamber. The $\mathrm{pH}$ of the mixed sludge in the anode chambers (7.71) was not adjusted (Table 1). The anode chambers were mixed with magnetic stirring and the cathode chambers were mixed with aeration. The dissolved oxygen (DO) in the cathode chambers was kept at about $5.0 \mathrm{mg} / \mathrm{L}$ in order to maintain enough dissolved oxygen in the mixed liquid [3]. In order to maintain the volume of the mixed liquid in the cathode chambers, deionized water was supplied periodically. The MFCs were operated at room temperature $\left(25-34^{\circ} \mathrm{C}\right)$ and the tests were carried out in triplicate, and all results were means of replicate analyses.

\section{Analytical methods and calculations of electrical parameters}

The soluble chemical oxygen demand (SCOD) and total chemical oxygen demand (TCOD) of the sludge samples were quantified using an $\mathrm{HACH} \mathrm{COD}$ measurement system and kit (HACH Co., USA). Sludge samples were filtered using $0.45-\mu \mathrm{m}$ membranes before determining their SCOD. The $\mathrm{pH}$ of sludge was measured with a pH meter (Sartorius PB-10, Germany). The sludge concentration (total suspended solids, TSS and volatile suspended solids, VSS) was measured according to the standard methods [1].

Biogas production in the anode chambers of MFCs was measured periodically by displacement of saturated aqueous $\mathrm{NaCl}$ in a graduated cylinder [14]. The biogas in the headspace of the anode chambers was sampled with a $1 \mathrm{ml}$ gas-tight syringe. The content of methane $\left(\mathrm{CH}_{4}\right)$ in the biogas was analyzed by a gas chromatograph (Agilent 6890, USA) equipped with a flame ionization detector (FID) and a $30 \mathrm{~m}$ capillary column (HP-5), and nitrogen was used as the carrier gas with a flow rate of $30 \mathrm{ml} / \mathrm{min}$.

The output voltages of MFCs were recorded using a precision digital multimeter and a data acquisition system (Beijing Ruibohua Co. China) connected to a computer. The polarization curves were measured by varying external resistances from 50,000 to $0 \Omega$ with an interval of 2 min to gain stable voltages when the MFC performance was stable. The open circuit voltage, internal resistance and maximal power density were obtained from analysis of the polarization curves. 
Table 1 - Some characteristics of sludge used in the test.

\begin{tabular}{lcrrrr} 
Item & $\mathrm{pH}$ & \multicolumn{1}{c}{$\begin{array}{c}\mathrm{TCOD} \\
(\mathrm{mg} / \mathrm{L})\end{array}$} & $\begin{array}{r}\text { SCOD } \\
(\mathrm{mg} / \mathrm{L})\end{array}$ & \multicolumn{1}{c}{$\begin{array}{c}\text { TSS } \\
(\mathrm{g} / \mathrm{L})\end{array}$} & $\begin{array}{c}\text { VSS } \\
(\mathrm{g} / \mathrm{L})\end{array}$ \\
\hline Raw sludge & $7.5( \pm 0.1)$ & $10,260( \pm 120)$ & $75( \pm 20)$ & $14.92( \pm 0.22)$ & $9.87( \pm 0.15)$ \\
Anaerobic sludge & $7.9( \pm 0.1)$ & $4860( \pm 110)$ & $1120( \pm 30)$ & $6.57( \pm 0.27)$ & $3.81( \pm 0.22)$ \\
Mixed sludge in the anode chamber & $7.71( \pm 0.1)$ & $9720( \pm 110)$ & $225( \pm 21)$ & $13.88( \pm 0.24)$ & $9.11( \pm 0.31)$ \\
\hline
\end{tabular}

\section{DNA extraction, PCR, DGGE and sequencing}

The sludge on the anodes and in the anode chambers of the two MFCs was sampled at $0 \mathrm{~d}, 20 \mathrm{~d}$ and $34 \mathrm{~d}$ of the test, respectively, and the microbial communities of the samples were analyzed using molecular biological methods (PCRDGGE). The DNA of sludge samples was extracted by a nucleic acid automatic extraction system (TANBead Smart LabAssist16, Taiwan). The extracted DNA was then used as a template for PCR amplification.

The eubacterial universal primers, 357F (5'-CCTACGGGAGGCAGCAG-3') and 517R (5'-ATTACCGCGGCTGCTGG-3'), were used to amplify a segment of the eubacterial $16 \mathrm{~S}$ rDNA [31]. For Archaea 16S rDNA, the PCR primers were 344F ( $5^{\prime}-$ GACGGGGHGCAGCAGGCGCGA-3') and 522R (5'-GWATTACCGCGGCKGCTG-3') [22]. A GC-clamp was added to the forward primers to facilitate DGGE. PCR amplification was performed using a PTC-200 thermal cycler (BioRad Laboratories, USA) at a final volume of $50 \mu$ l. The reaction mixture contained $1 \mu \mathrm{l}$ of both primers $(10 \mu \mathrm{M}), 4 \mu \mathrm{l}$ of each dNTP, $5 \mu \mathrm{l}$ of $10 \times$ buffer, 50 ng DNA template, and 1.5 units of Taq DNA polymerase. The condition of PCR for eubacteria was $94^{\circ} \mathrm{C}$ for $5 \mathrm{~min}$, followed by 30 cycles of $94^{\circ} \mathrm{C}$ for $1 \mathrm{~min}, 48^{\circ} \mathrm{C}$ for $1 \mathrm{~min}$ and $72{ }^{\circ} \mathrm{C}$ for $1 \mathrm{~min}$ and a final extension at $72{ }^{\circ} \mathrm{C}$ for $10 \mathrm{~min}$. The condition of touchdown PCR for Archaea was $94{ }^{\circ} \mathrm{C}$ for $5 \mathrm{~min}$, followed by 10 cycles of $94^{\circ} \mathrm{C}$ for $30 \mathrm{~s}, 68^{\circ} \mathrm{C}-58^{\circ} \mathrm{C}$ for $30 \mathrm{~s}, 72{ }^{\circ} \mathrm{C}$ for $1 \mathrm{~min}$ and $-1{ }^{\circ} \mathrm{C} / \mathrm{cycle}$; and 20 cycles of $94^{\circ} \mathrm{C}$ for $30 \mathrm{~s}, 58^{\circ} \mathrm{C}$ for $30 \mathrm{~s}$ and $72^{\circ} \mathrm{C}$ for $1 \mathrm{~min}$; and a final extension at $72{ }^{\circ} \mathrm{C}$ for $10 \mathrm{~min}$. A $5 \mu \mathrm{l}$ aliquot of the PCR product was separated on a $0.8 \%(\mathrm{w} / \mathrm{v})$ agarose gel at $100 \mathrm{~V}$ for $30 \mathrm{~min}$ to verify amplification prior to DGGE.

The DGGE of PCR-amplified 16S rDNA was performed using a D-Code system (BioRad Laboratories). 40-70\% denaturing gradients were used to separate the amplified $16 \mathrm{~S}$ rDNA. The gel was electrophoresed in $1 \times \mathrm{TAE}$ buffer at $70 \mathrm{~V}$ and $60^{\circ} \mathrm{C}$ for $10 \mathrm{~h}$. The resulting gel was then visualized using Gel Red (Biotium, USA). The analysis of the DGGE gel was conducted using the Bio-Rad software, Quantity One ${ }^{\mathrm{TM}}$. The prominent DGGE bands were excised to submit for sequencing using the ABI 3730DXL DNA sequencer (AB, USA). A phylogenetic tree including sequences of this work and related sequences from the previous NCBI database was constructed using the neighbor joining algorithm by MEGA version 5.05.

\section{Results and discussion}

\section{Methane and electricity production from sewage sludge}

The production of methane in the anode chambers was detected in the electricity-producing process of the two MFCs, and the results are summarized in Fig. 1. The addition of BES could completely inhibit the methane production, and no methane was produced in the anode chamber of the MFC with $\mathrm{BES}$, while methane could be detected in the anode chamber of the MFC without BES (Fig. 1). The methane production for the MFC without BES reached $318.3 \mathrm{ml}$ at the end of the tests (34 d). From Fig. 1, it could be found that the methane production process of the sludge (namely an increase in the form of an S-shaped curve) in the anode chamber of the MFC without BES was similar to that in previous studies $[24,30]$. The methane yield of sludge, calculated according to the initial sludge concentration in the anode chamber, reached about $87.0 \mathrm{ml} \mathrm{CH}_{4} / \mathrm{g}$ VSS at the end of the test (34 d), which was similar to a previous study [30].

Electricity production from the sewage sludge in the twochamber MFCs was determined and the results are summarized in Fig. 2. It could be observed that the electricity production of the two MFCs was different, and the electricityproducing process could be divided into three stages: $0 d-11 d, 11 d-16 d$ and $16 d-37 d$. In the first stage ( $0 d-11 d$ ), the voltages of the MFC with BES were higher than those of the MFC without BES, and they varied in the range $0.488 \mathrm{~V}-0.576 \mathrm{~V}$ (MFC with BES) and $0.468 \mathrm{~V}-0.564 \mathrm{~V}$ (MFC without BES), respectively. In the second stage (11-16 d), the voltage outputs of the two MFCs were similar and they varied in the range $0.546 \mathrm{~V}-0.572 \mathrm{~V}$. In the third stage $(16 \mathrm{~d}-37 \mathrm{~d})$, the voltages of the MFC without BES were higher than those of the MFC with BES and they varied in the ranges $0.533 \mathrm{~V}-0.600 \mathrm{~V}$ (MFC without BES) and $0.506 \mathrm{~V}-0.576 \mathrm{~V}$ (MFC with $\mathrm{BES})$, respectively. Additionally, the time for the two MFC to enter the stable electricity-producing stage was different: 7 days for the MFC without BES and 4 days for the MFC with BES. In the stable

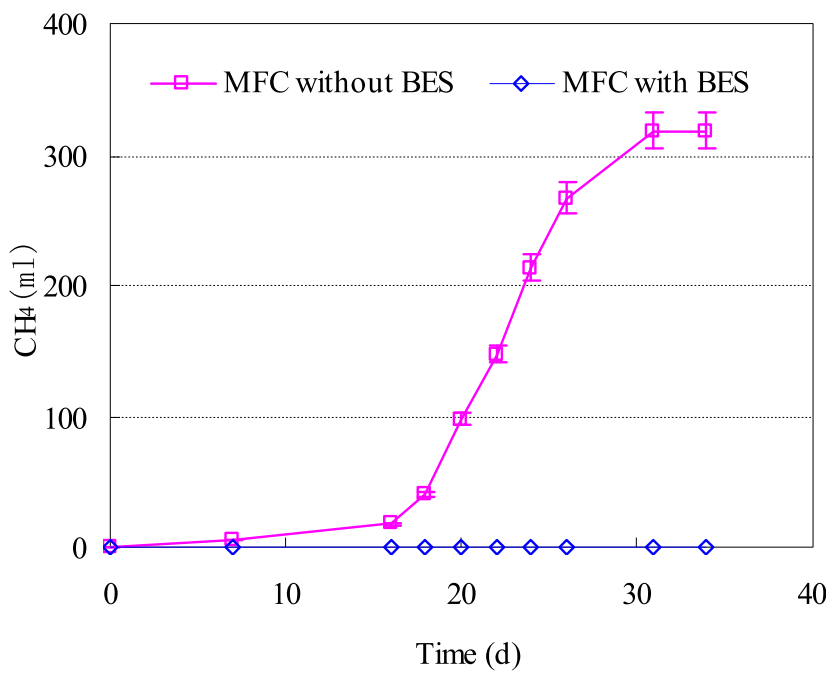

Fig. 1 - Methane production in the anode chambers. 


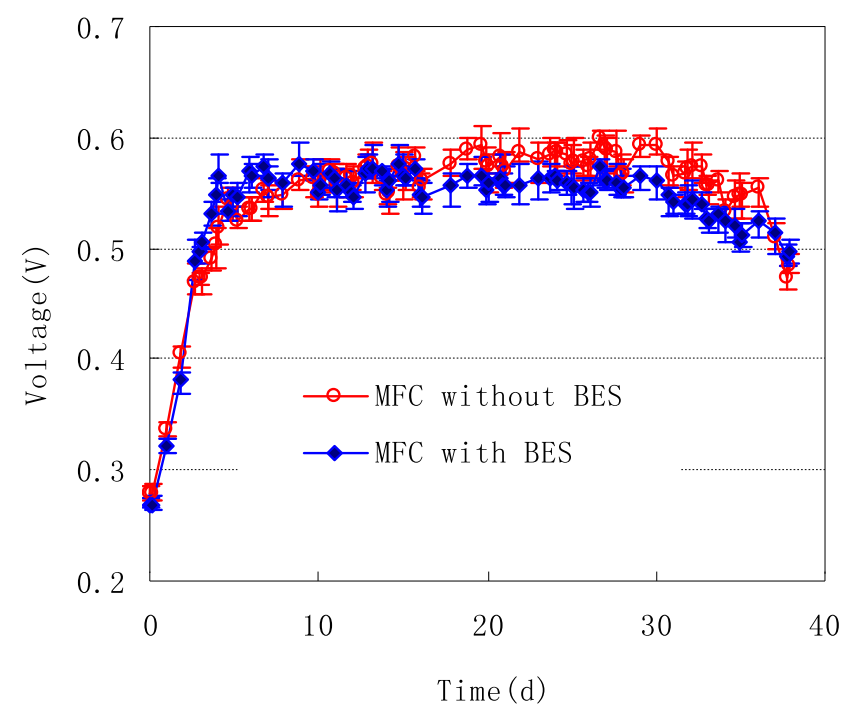

Fig. 2 - Electricity production from the sewage sludge in the MFCs.

electricity-producing stage (7-37 d for MFC without BES and 4-37 $d$ for MFC with BES), the voltage output of the MFC with BES was $0.506 \mathrm{~V}-0.576 \mathrm{~V}$, while that of the MFC without BES was $0.505 \mathrm{~V}-0.600 \mathrm{~V}$. The results showed that the methanogenesis in the anode chamber of MFC with sewage sludge as the electricity-producing substrate could enhance the electricity production from sewage sludge in the later stages (16 d-37 d). The result was different from previous studies $[2,9,21,33]$. For example [33], found the output voltages topped at $0.62 \mathrm{~V}$ and $0.54 \mathrm{~V}$ for the MFCs with and without BES, respectively. When the methanogenesis was inhibited by BES $[2,9,33]$, found that the coulombic efficiency increased from $40 \%-70 \%, 35 \%-70 \%$ and $4.1 \%-7.8 \%$, respectively. This difference may be caused by the different electricity-producing substrates used. In previous studies, most of the electricityproducing substrates were simple (like acetate, sodium acetate, glucose and cellulose) and limited [2,9,21]. In this study, however, the electricity-producing substrate was sewage sludge, which contains abundant and complex organic matter. The different substrates would result in different environmental conditions and changes in the anode chamber for electricity production, which will be discussed in the following text. Meanwhile, comparing the electricity and methane producing processes (Figs. 1 and 2), it was found that the electricity production of the MFC without BES was higher than that of the MFC with BES after methanogenesis was increased (after $16 \mathrm{~d}$ ). The result suggested that rapid methane production may enhance the electricity production from sewage sludge.

The polarization curves of the two MFCs were measured in the electricity-producing process (4th $d, 11$ th $d, 20$ th $d$ and 34th d, respectively), with the results summarized in Fig. 3, and three parameters of the two MFCs were obtained by analysis of these polarization curves (Table 2). The open circuit voltage of the MFC with BES was higher than that of the MFC without BES at the 4th d, 11th d and 20th d, and was lower at the 34th $\mathrm{d}$. The maximal power densities of the two MFCs were increased from 4 th $d$ to 20 th $d$ and decreased from 20 th

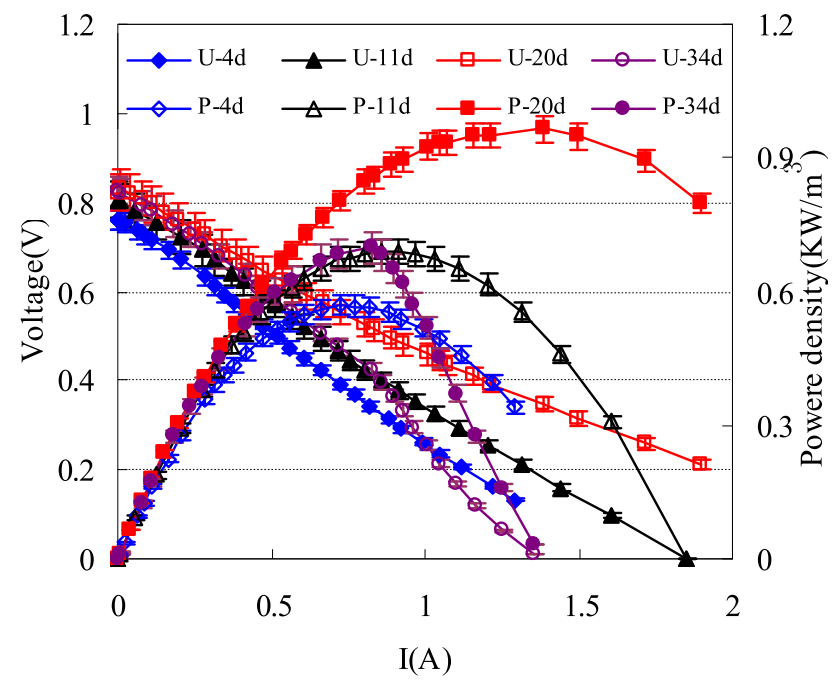

\section{A: MFC without BES}

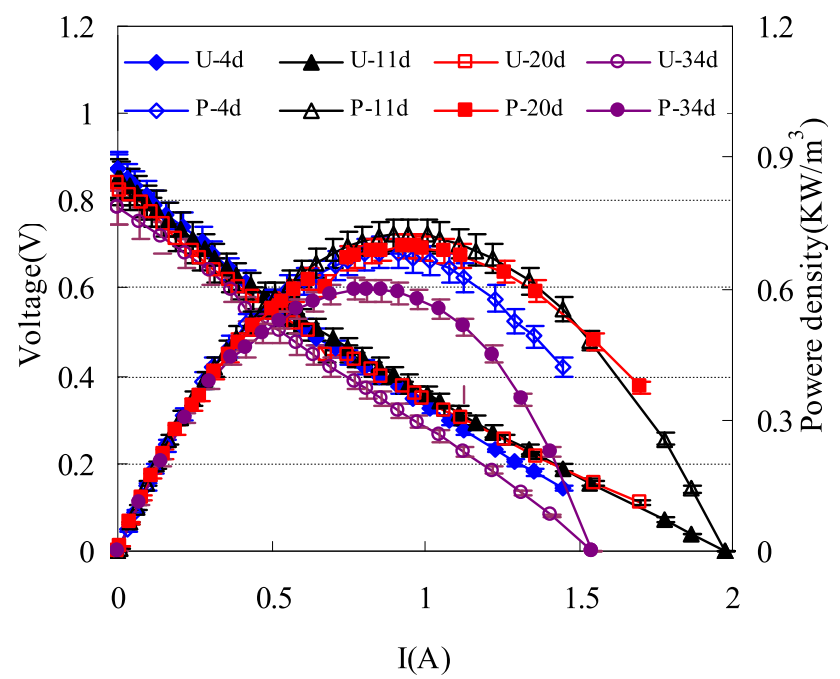

B: MFC with BES

Fig. 3 - The polarization curves of the two MFCs during the test.

$d$ to 34th $d$. Comparing the maximal power densities of the two MFCs in the electricity-producing process, the highest maximal power density was $0.965 \mathrm{Kw} / \mathrm{m}^{3}$ at the 20 th $\mathrm{d}$ (MFC without BES). The changes in internal resistance of the two MFCs were similar: an increase from 4th $d$ to 20th $d$ and decreased from 20 th $d$ to 34 th $d$. The minimal internal resistances of the two MFCs were $412 \Omega$ (MFC with BES) and $371 \Omega$ (MFC without BES) at the 20th day, respectively. The polarization curves of the two MFCs suggested that the performance characteristics of the MFC without BES was better than those of the MFC with BES.

\section{Changes of liquid phase in the anode chambers}

The action of microorganisms in the anode chamber of an MFC results in a change in sludge $\mathrm{pH}$ : The $\mathrm{pH}$ of sludge 
Table 2 - Change of three parameters of the two MFCs during the test.

\begin{tabular}{ccccc} 
Item & Day & $\begin{array}{c}\text { Open circuit } \\
\text { voltage } \\
(\mathrm{V})\end{array}$ & $\begin{array}{c}\text { Maximal power } \\
\text { density } \\
\left(\mathrm{Kw} / \mathrm{m}^{3}\right)\end{array}$ & $\begin{array}{c}R_{\text {int }} \\
(\Omega)\end{array}$ \\
\hline \multicolumn{2}{c}{ MFC without 4 th } & $0.763( \pm 0.007)$ & $0.571( \pm 0.012)$ & $507( \pm 13)$ \\
BES & 11th & $0.806( \pm 0.010)$ & $0.689( \pm 0.013)$ & $450( \pm 16)$ \\
& 20th & $0.822( \pm 0.009)$ & $0.965( \pm 0.015)$ & $371( \pm 17)$ \\
MFC with & 34th & $0.823( \pm 0.011)$ & $0.700( \pm 0.009)$ & $498( \pm 11)$ \\
BES & 4th & $0.875( \pm 0.008)$ & $0.696( \pm 0.011)$ & $509( \pm 12)$ \\
& 20th & $0.851( \pm 0.007)$ & $0.724( \pm 0.012)$ & $417( \pm 10)$ \\
& 34th & $0.838( \pm 0.011)$ & $0.853( \pm 0.014)$ & $412( \pm 13)$ \\
& & & &
\end{tabular}

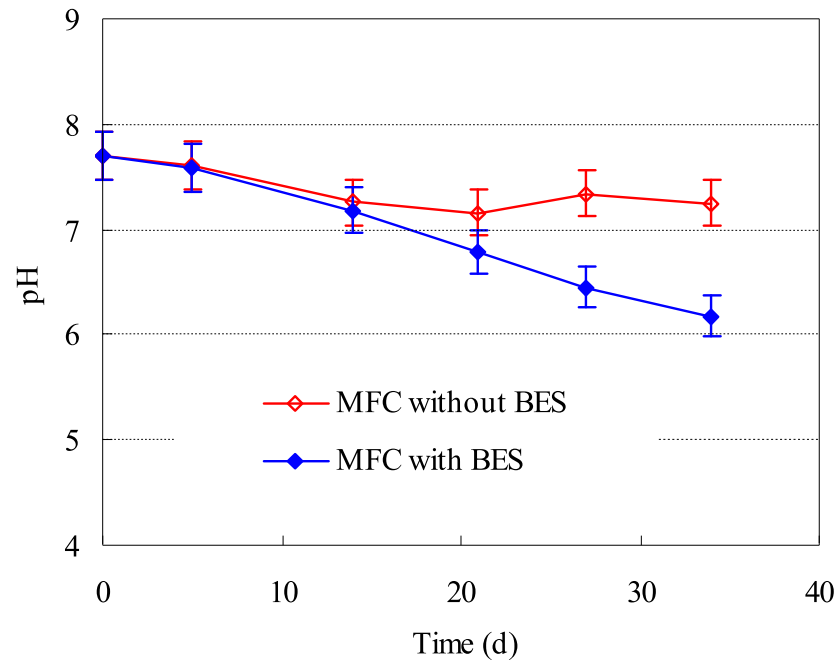

Fig. 4 - Change of sludge pH during the test.

decreases in the first three stages of anaerobic sludge digestion (hydrolysis, acidogenesis and acetogenesis) and increases in the last stage (methanogenesis) [19], while the $\mathrm{pH}$ of sludge in the anode chamber decreases during the electricity production $[7,10]$. So, the changes of $\mathrm{pH}$ for sludge in the anode chambers of the two MFCs were measured in the test (Fig. 4). In the 0-14 $\mathrm{d}$ stage, the $\mathrm{pH}$ of sludge in the anode chambers decreased from 7.71 to 7.18 (MFC with BES) and 7.26 (MFC without BES), respectively. After $14 \mathrm{~d}$, different changes in sludge $\mathrm{pH}$ in the anode chamber for the two MFCs were observed: that for the MFC with BES continued to decrease (From 7.18 to 6.18) while that for the MFC without BES was stable (about 7.25). When BES was added in the anode chamber of an MFC, no methanogenesis occurred, and the other actions (hydrolysis, acidogenesis, acetogenesis and electricity production) resulted in changes in the sludge $\mathrm{pH}$. On the contrary, the change of sludge $\mathrm{pH}$ was the balanced result of all actions in the MFC without BES. In other words, methanogenesis resulted in different changes in the sludge $\mathrm{pH}$ in the anode chambers of the two MFCs: in the 0-14 d stage, the methanogenesis in the anode chambers of the two MFCs was lower and their sludge $\mathrm{pH}$ values decreased; while after $14 \mathrm{~d}$, the methanogenesis in the anode chamber of the MFC without BES increased and its sludge $\mathrm{pH}$ was stable, and the sludge $\mathrm{pH}$ of the MFC with BES continued to decrease, which was similar to most previous studies with limited and simple organic matters $[6,15,32]$. Comparing the change of electricity production and sludge $\mathrm{pH}$ of the two MFCs (Figs. 2 and 4), it could be found that the electricity production of the MFC without BES was higher than that of the MFC with BES when the changes of sludge $\mathrm{pH}$ in the anode chambers of the two MFCs were different. This is because neutral $\mathrm{pH}$ is optimal for the growth of bacteria and electricity production of an MFC $[6,15,32]$. Thus, the result showed that simultaneous methane and electricity production from sludge in the anode chamber of an MFC could maintain the $\mathrm{pH}$ of mixed sludge in a suitable range for electricity production.

The anaerobic fermentation and electricity production of the sludge resulted in a decrease in sludge concentration (Table 3). At the end of the test (37th $d$ ), the concentrations of sludge in the anode chambers of the two MFC were $6.94 \mathrm{~g} / \mathrm{L}$ (TSS), $3.40 \mathrm{~g} / \mathrm{L}$ (VSS) (MFC without BES) and 7.17 g/L (TSS), $4.16 \mathrm{~g} / \mathrm{L}$ (VSS) (MFC with $\mathrm{BES})$, respectively. The reductions of sludge in the test for the two anode chambers reached $50.32 \%$ (TSS) and $62.83 \%$ (VSS) (MFC without BES) and 48.31\% (TSS), 54.52\% (VSS) (MFC with $\mathrm{BES})$, respectively. The reduction of sludge was similar to that observed in previous studies, or even higher [17,25], which showed that the anaerobic digestion of sludge in the anode chambers of the two MFCs was normal. Since both the production of methane and electricity need to consume organic matters, the higher sludge reduction, especially higher reduction of VSS, is consistent with the higher methane and electricity production in the anode chamber of the MFC without BES. The results suggested that simultaneous methane and electricity production could enhance the reduction of sludge in the anode chamber of an MFC. Additionally, more sludge reduction in the anode chamber in turn could provide more substrates for electricity and methane production and the abundant organic matters released in the sludge reduction could alleviate their competition.

\section{Microbial communities of sludge in the anode chambers}

In order to clarify the effect of BES on the microbial communities, sludge samples on the anodes and in the anode

Table 3 - Change of sludge concentration in the anode chamber.

\begin{tabular}{|c|c|c|c|c|}
\hline \multirow[t]{2}{*}{ Item } & \multicolumn{2}{|c|}{ MFC without BES } & \multicolumn{2}{|c|}{ MFC with BES } \\
\hline & $0 \mathrm{~d}$ & $37 d$ & $0 \mathrm{~d}$ & $37 d$ \\
\hline $\mathrm{SS}(\mathrm{g} / \mathrm{L})$ & $13.88( \pm 0.11)$ & $6.94( \pm 0.09)$ & $13.88( \pm 0.13)$ & $7.17( \pm 0.12)$ \\
\hline VSS (g/L) & $9.15( \pm 0.12)$ & $3.40( \pm 0.13)$ & $9.15( \pm 0.11)$ & $4.16( \pm 0.10)$ \\
\hline SS reduction (\%) & - & $50.32( \pm 0.10)$ & - & $48.31( \pm 0.15)$ \\
\hline VSS reduction (\%) & - & $62.83( \pm 0.14)$ & - & $54.52( \pm 0.13)$ \\
\hline
\end{tabular}



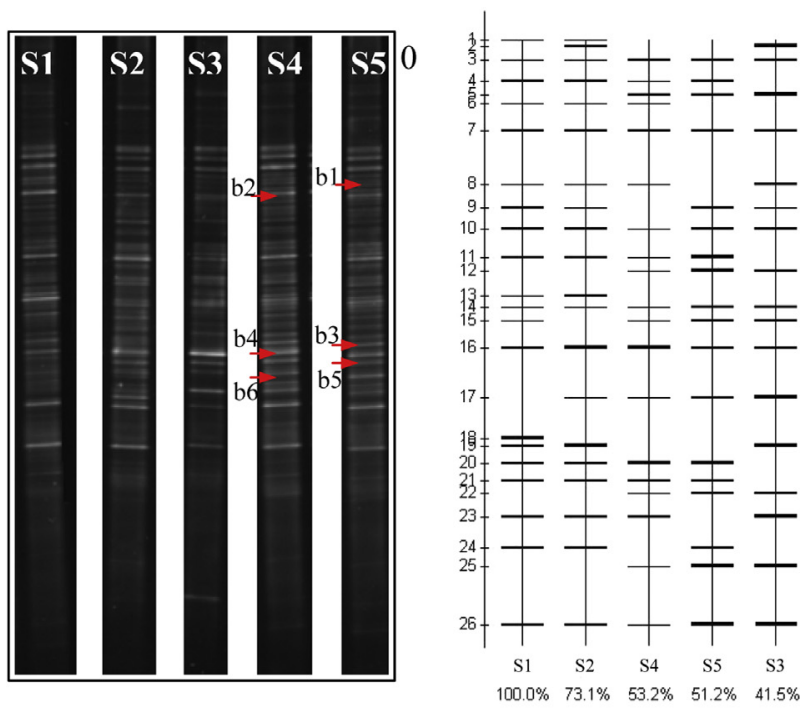

A: Bacteria
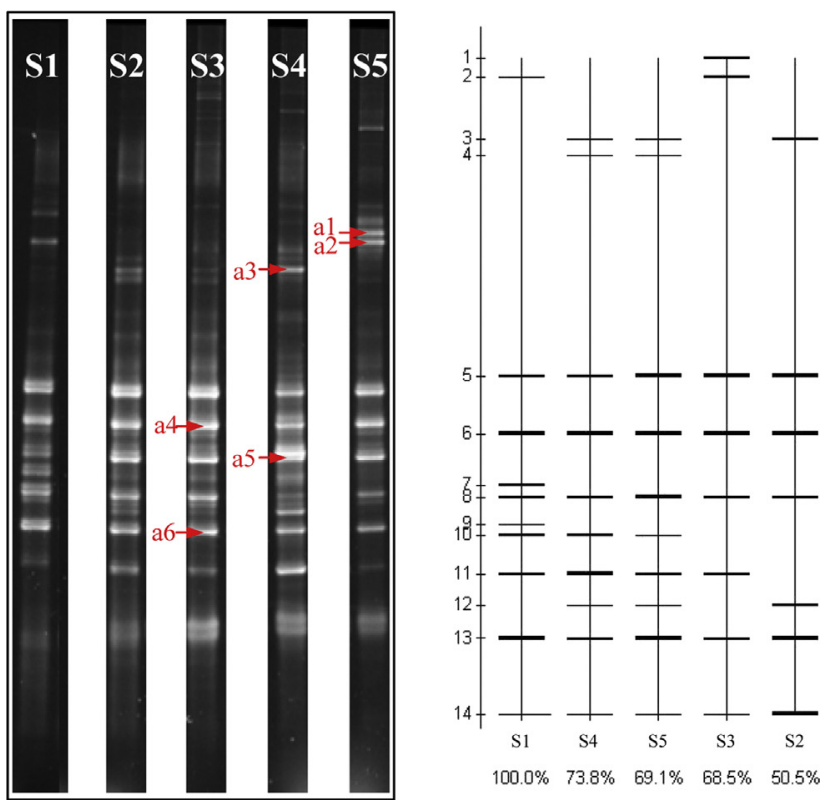

B: Archaea

Fig. 5 - DGGE profiles for sludge samples in the two anode chambers. S1: initial sample; S2: $15 \mathrm{~d}$ sample of MFC with BES; S3: $15 \mathrm{~d}$ sample of MFC without BES; S4: $34 \mathrm{~d}$ sample of MFC with BES; S5: $34 \mathrm{~d}$ sample of MFC without BES. chambers of the two MFCs were collected for analysis by DNA extraction, PCR, DGGE and sequencing, and the results are summarized in Fig. 5. The results showed that the diversity of bacteria was richer than that of archaea in the same sample. The results of similarity analysis on bands indicated that the BES had little effect on the bacterial structures of sludge in the anode chamber (Fig. 5-A). Unlike the eubacteria, the band similarity of archaea showed that the effect of BES on archaea was escalating with the extension of performance time. The dominant archaea of samples for the two MFCs was clearly different until 34 days of operation (S4 and S5 in Fig. 5-B). Different bands were excised from the DGGE gel and were sequenced. The sequences were then compared to those available in the GenBank database using BLASTN. All sequences were $96-100 \%$ homologous with previously identified 16S rRNA gene sequences. The sequencing of eubacteria showed that there were abundant bacteria for hydrolysis and acidification (like Clostridium sp., Lactobacillus sp. and Flavobacterium sp.) in the two anode chambers (band b1-b6), which suggested the hydrolysis and acidification of sludge was strong (Table 4). Meanwhile, Clostridium sp. was believed to correlate with electricity production [18] The sequencing of archaea showed that the dominant archaea were respectively affiliated with Methanolinea sp., Methanospirillum sp., Methanosarcina sp. and Methanosphaera sp. (band a1-a6). The above results suggested that the addition of BES could clearly affect the dominant archaea (especially methanogens) and only slightly affect the dominant bacteria (including electricityproducing bacteria). The result was similar to that of [33] who found the microbial community of the anode was changed due to the addition of BES in the anode chamber. Additionally, some methanogens could also be detected in the sludge from the MFC with BES (Fig. 5-B and Table 4). This may be due to the fact that the addition of BES could only inhibit the activity of methanogens, but could not kill them [33].

\section{Conclusions}

Methane production in the anode chamber of MFC using sewage sludge as substrate could increase the electricity production and enhance the performance of the MFC, and the output voltages of the MFC with methane production $(0.505 \mathrm{~V}-0.600 \mathrm{~V})$ were higher than that of the MFC without it (0.506 V-0.576 V). Simultaneous methane and electricity production from sludge could maintain a suitable $\mathrm{pH}$ range for electricity production. Meanwhile, the processes could enhance the hydrolysis and reduction of sludge, which resulted in more substrates for electricity production and the

Table 4 - Sequence identities and characteristics of bacterial clones that appeared in Fig. 5.

\begin{tabular}{llcclc} 
Band & \multicolumn{1}{c}{ Closest relatives } & Similarity & Band & \multicolumn{1}{c}{ Closest relatives } & Similarity \\
\hline b1 & Lactobacillus johnsonii & $100 \%$ & a1 & Uncultured Methanosphaera sp. & $100 \%$ \\
b2 & Flavobacterium sp. & $100 \%$ & a2 & Uncultured Methanolinea sp. & S9\% \\
b3 & Uncultured Clostridium sp. & $100 \%$ & a3 & Uncultured Methanosarcina sp. \\
b4 & Uncultured Clostridia bacterium & $98 \%$ & a4 & Uncultured Methanolinea sp. & $99 \%$ \\
b5 & Uncultured Clostridia bacterium & $98 \%$ & a5 & Uncultured Methanosarcina sp. & $99 \%$ \\
b6 & Uncultured Clostridium sp. & $100 \%$ & a6 & Uncultured Methanospirillum sp. & $99 \%$ \\
\hline
\end{tabular}


abundant substrates could alleviate the competition between methane and electricity production in the MFC.

\section{Acknowledgments}

The authors kindly thank Dr. Watts for the English revision of this manuscript. This work was financially supported by the Major Science and Technology Program for Water Pollution Control and Treatment (No. 2012ZX07203-001) and the National Nature Science Foundation of China (No. 51221892 and No. 51108043).

\section{R E F E R E N C E S}

[1] APHA. Standard methods for the examination of water and wastewater. 20th ed. 1998 [Washington, DC, USA].

[2] Chae KJ, Choi MJ, Kim KY, Ajayi FF, Park W, Kim CW, et al. Methanogenesis control by employing various environmental stress conditions in two-chambered microbial fuel cells. Bioresour Technol 2010;101:5350-7.

[3] Deng Q, Li X, Zuo J, Ling A, Logan BE. Power generation using an activated carbon fiber felt cathode in an upflow microbial fuel cell. J Power Sources 2010;195:1130-5.

[4] Durruty I, Bonanni PS, González JF, Busalmen JP. Evaluation of potato-processing wastewater treatment in a microbial fuel cell. Bioresour Technol 2012;105:81-7.

[5] Ge Z, Zhang F, Grimaud J, Hurst J, He Z. Long-term investigation of microbial fuel cells treating primary sludge or digested sludge. Bioresour Technol 2013;136:509-14.

[6] Gil GC, Chang IS, Kim BH, Kim M, Jang JK, Park HS, et al. Operational parameters affecting the performance of a mediator-less microbial fuel cell. Biosens Bioelectron 2003;18:327-34.

[7] He Z, Minteer SD, Angenent LT. Electricity generation from artificial wastewater using an upflow microbial fuel cell. Environ Sci Technol 2005;39:5262-7.

[8] Jiang JQ Zhao QL, Zhang JN, Zhang GD, Lee DJ. Electricity generation from bio-treatment of sewage sludge with microbial fuel cell. Bioresour Technol 2009;100:5808-12.

[9] Kim JR, Min B, Logan BE. Evaluation of procedures to acclimate a microbial fuel cell for electricity production. Appl Microbiol Biotechnol 2005;68:23-30.

[10] Liang P, Guo C, Huang X. Using hydrolyzed sludge liquor as the substrate of microbial fuel cell. J Electrochem 2013;19:332-5 [in Chinese].

[11] Logan BE, Hamelers B, Rozendal R, Schröder U, Keller J, Freguia S, et al. Microbial fuel cells: methodology and technology. Environ Sci Technol 2006;40:5181-92.

[12] Lovley DR, Phillips EJP. Novel mode of microbial energy metabolism: organic carbon coupled to dissimilatory reduction of iron or manganese. Appl Environ Microbiol 1988;54:1472-80.

[13] Lu N, Zhou SG, Zhuang L, Zhang JT, Ni JR. Electricity generation from starch processing wastewater using microbial fuel cell technology. Chem Eng J 2009;43:246-51.

[14] Moosvi S, Madamwar D. An integrated process for the treatment of CETP wastewater using coagulation, anaerobic and aerobic process. Bioresour Technol 2007;98:3384-92.

[15] Oliveira VB, Simoes M, Melo LF, Pinto AMFR. Overview on the developments of microbial fuel cells. Biochem Eng J 2013;73:53-64.
[16] Osman MH, Shah AA, Walsh FC. Recent progress and continuing challenges in bio-fuel cells. Part II Microbia Biosens Bioelectron 2010;26:953-63.

[17] Pant D, Van Bogaert G, Diels L, Vanbroekhoven K. A review of the substrates used in microbial fuel cells (MFCs) for sustainable energy production. Bioresour Technol 2010;101:1533-43.

[18] Park HS, Kim BH, Kim HS, Kim HJ, Kim GT, Kim M, et al. A novel electrochemically active and Fe(III)-reducing bacterium phylogenetically related to Clostridium butyricum isolated from a microbial fuel cell. Anaerobe 2001;7:297-306.

[19] Parkin GF, Owen WF. Fundamentals of anaerobic digestion of wastewater sludges. J Environ Eng ASCE 1986;112:867-920.

[20] Rabaey K, Verstraete W. Microbial fuel cells: novel biotechnology for energy generation. Trends Biotechnol 2005;23:291-8.

[21] Rismani-Yazdi H, Carver SM, Christy AD, Yu Z, Bibby K, Peccia J, et al. Suppression of methanogenesis in cellulosefed microbial fuel cells in relation to performance, metabolite formation, and microbial population. Bioresour Technol 2013;129:281-8.

[22] Röling WFM, Ortega-Lucach S, Larter SR, Head IM. Acidophilic microbial communities associated with a natural, biodegraded hydrocarbon seepage. J Appl Microbiol 2006;101:290-9.

[23] Tyagi VK, Lo S-L. Sludge: a waste or renewable source for energy and resources recovery? Renew Sust Energ Rev 2013;25:708-28.

[24] Wang Q, Kuninobu M, Kakimoto K, Ogawa HI, Kato Y. Upgrading of anaerobic digestion of waste activated sludge by ultrasonic pretreatment. Bioresour Technol 1999;68:309-13.

[25] Wang Z, Ma J, Xu Y, Yu H, Wu Z. Power production from different types of sewage sludge using microbial fuel cells: a comparative study with energetic and microbiological perspectives. J Power Sources 2013;235:280-8.

[26] Weemaes MPJ, Verstraete WH. Evaluation of current wet sludge disintegration techniques. J Chem Technol Biotechnol 1998;73:83-92.

[27] Wilson CA, Novak JT. Hydrolysis of macromolecular components of primary and secondary wastewater sludge by thermal hydrolytic pretreatment. Water Res 2009;43:4489-98.

[28] Wong YM, Wu TY, Juan JC. A review of sustainable hydrogen production using seed sludge via dark fermentation. Renew Sust Energ Rev 2014;34:471-82.

[29] Xiao B, Yang F, Liu J. Evaluation of electricity production from alkaline pretreated sludge using two-chamber microbial fuel cell. J Hazard Mater 2013;254-255:57-63.

[30] Zhang D, Chen Y, Zhao Y, Zhu X. New sludge pretreatment method to improve methane production in waste activated sludge digestion. Environ Sci Technol 2010;44:4802-8.

[31] Zhang D, Yuan X, Guo P, Suo Y, Wang X, Wang W, et al. Microbial population dynamics and changes in main nutrients during the acidification process of pig manures. J Environ Sci China 2011a;23:497-505.

[32] Zhang L, Li C, Ding L, Xu K, Ren H. Influences of initial pH on performance and anodic microbes of fed-batch microbial fuel cells. J Chem Technol Biotechnol 2011b;86:1226-32.

[33] Zhuang L, Chen Q, Zhou S, Yuan Y, Yuan H. Methanogenesis control using 2-Bromoethanesulfonate for enhanced power recovery from sewage sludge in air-cathode microbial fuel cells. Int J Electrochem Sci 2012;7:6512-23.

[34] Zinder SH, Anguish T, Cardwell SC. Selective inhibition by 2 bromoethanesulfonate of methanogenesis from acetate in a thermophilic anaerobic digestor. Appl Environ Microbiol 1984;47:1343-5. 